Nevşehir Bilim ve Teknoloji Dergisi Cilt 6(2) 594-604 2017

DOI: 10.17100/nevbiltek.335788

URL: http://dx.doi.org/10.17100/nevbiltek.335788

\title{
Bitki Patojeni Virüslerin Nanoteknolojide Kullanımı
}

\author{
Diğdem OKSAL ${ }^{*}$, Fatih ÖRS \\ İnönü Üniversitesi Ziraat Fakültesi Bitki Koruma Bölümü, Malatya
}

$\ddot{O} z$

Bitki virüsleri nanobiyoteknolojide konukçularında çok miktarda antijenik materyal üretmeleri nedeni ile sıklıkla kullanılmaktadır. Bitki virüslerinin şablon olarak kullanıldığı biyomateryaller, biyonanobilim araştırmalarının bir alt alanında, nanoölçek düzeyinde cihazların üretiminde ya da yöntemlerin hazırlanmasında kullanılmaktadır. Bitki patojeni virüslerden, ayrıca, viral nanopartikül olarak tıpta yararlanılmakta, biyokatalizör olarak kullanılmakta, tarımda bitki patojenlerinin kontrolünde de yararlanılmaktadır. Bu makalede bitki virüslerinden nanobiyoteknolojide yararlanma olanakları derlenmiștir.

Anahtar Kelimeler: Virüs, bitki patojeni, nanoteknoloji

\section{Usage of Plant Pathogenic Viruses in Nanotechnology}

\section{Abstract}

Plant viruses are increasingly being developed for applications in nanobiotechnology because of their potential for producing large quantities of antigenic material in plant hosts. The obtained biomaterials from plant viruses are used in the production of nanoscale devices or in the preparation of methods in a sub-area of bionanosim. Plant pathogenic viruses are used as templates for the production of new materials in nanotechnology. Plant pathogenic viruses also utilize as viral nanoparticle in medicine, are used as biocatalysts, and are also used in the control of plant pathogens in agriculture. In this review the opportunity of use of plant virus particles in nanobiotechnology is highlighted.

Keywords: Virus, plant pathogenic, nanotechnology

"e-mail: hatice.oksal@inonu.edu.tr 


\section{Giriş}

Nano, metrik bir sistemin içinde bir ölçü birimi olarak kullanılır ve milyarda bir anlamına gelmektedir. "Nano" kelimesi Yunancadan ve Latinceden alınmış bir sözcüktür ve anlamı cüce demektir. Nano ve nano teknolojinin tam manasıyla bir tanımı bulunmamakla birlikte, genel görüşe göre 1-100 nanometre boyutlarda maddelerin anlaşılması, kontrol edilmesi ve atomsal seviyede değiştirilip işlevsel hale getirilmesi olarak tanımlanabilir. Nano teknolojide ölçü olarak nanometre (nm) adı verilen bir ölçme birimini kullanılır. Kimya, biyoloji, fizik, tıp, mühendislik ve malzeme bilimi arayüzünde nanoteknolojiden yararlanılmaktadır. Elde edilen biyomateryaller, biyonanobilim araştırmalarının bir alt alanında, nanoölçek düzeyinde cihazların üretiminde ya da yöntemlerin hazırlanmasında kullanılmaktadır. Douglas ve Young, ilk olarak 1998'li y1llarda bitki virüslerini yeni inorganik nanomateryal üretiminde kullanarak bu işin öncülüğünü yapmışlardır [1]. Bu yaklaşım, biyonanobilimin araştırma alanına girmektedir.

Biyonanobilim, nanobilimin bir alt bölümüdür ve biyomateryaller, cihazlar ya da nano ölçekte yöntemlerden yararlanmayı içermektedir. Multidisipliner bir bilim dalı olduğu için kimya, fizik, tıp, mühendislik ve malzeme bilimlerinin arayüzünde yer almaktadır. Biyonanobilimin konusu iki ana bölüme ayrılmaktadır. Birincisi nanoteknolojik cihazların kullanımında biyolojik sistemleri kullanmak, ikincisi ise yeni nanomateryal veya cihazın üretiminde biyomateryallerden yararlanmaktır. Nanosistemler ya makroskobik materyallere daha küçük özellikler ekleyerek mikrofabrikasyon üretmeye ya da supramoleküler kimyayı kullanarak küçük molekülleri büyük hale getirmeye yaramaktadır [1].

\subsection{Nanoteknolojide Kullanılan Bitki Patojeni Virüsler}

Virüsler, bir nükleik asitten (RNA veya DNA) ve onu çevreleyen protein kılıftan (kapsid) oluşur. Nükleik asit genetik bilgiyi kodlarken, kapsid nükleik asidi korumaktadır. Virüslerle ilgili yoğun çalışmalar yapılmış ve biyolojik, genetik ve fiziksel özellikleri tanımlanmıştır. Bitki virüsleri, bitkiler dışındaki diğer organizmaları enfekte etmez ve onlar için biyolojik tehlike arz etmezler. Virüs partikülllerinin saflaştırılması kolay ve hızlıdır. Doğal konukçularında çoğalııldıklarında, hızlı bir şekilde saflaştırılabilirler. Bazı bitki virüs partikülleri,1 kg'lık enfekteli bitki materyalinden 2-4 haftalık bir süre içerisinde gram seviyesinde elde edilebilir [2].

Bir organizmaya ait bir proteinin, o proteini kodlayan gen veya cDNA nın bir vektör sistemi aracılığılya farklı bir sisteme aktarılıp üretilmesi demek olan heterolog sentezleme sistemleri virüs benzeri partiküllerden yüksek verim alınmasını sağlayabilir [3]. Viral kapsitler son derece stabil olup, geniş bir pH aralığında canlı kalabilir. Organik çözücü-su karışımlarına dayanabilir ve yüksek sıcaklıkları tolere edebilir. Çok sayıda bitki virüsü, bu özellikleri nedeniyle nano/mikro ölçekli malzeme üretimi için potansiyel kullanımları farklı araştırıcılar tarafından araştırılmış̧ır [1]. Bu virüsler arasında börülce klorotik benek virüsü (Cowpea chlorotic mottle virus, CCMV), brom otu mozaik virüsü (Brome mosaic virus, BMV), hıyar mozaik virüsü (Cucumber mosaic virus, CMV), kırmızı yonca nekrotik mozaik virüsü (Red clover necrotic mosaic virus, RCNMV), karanfil benek virüsü (Carnation mottle virus), börülce mozaik virüsü (Cowpea mosaic virus, CPMV), şalgam sarı mozaik virüsü (Turnip yellow mosaic virus, TYMV) ve tütün mozaik virüsü (Tobacco mosaic virus, TMV) yer almaktadır [1,9]. 
CCMV, BMV ve CMV Bromoviridae familyasından üç parçalı, tek sarmallı (ss) RNA içeren virüslerdir. CCMVve BMV'nin çapları yaklşık $28 \mathrm{~nm}$ uzunluğundadır [4,5]. CMV biraz daha büyük bir çapa sahip olması dışında CCMV'ye benzer, çapı yaklaşık 30.5 nm'dir [6]. CCMV'nin doğal konukçularından, enfekte olmuş yaprak dokusunun her bir gramından 1-2 mg virüs partikülü elde edilebilir. Mayalarla heterolog sentezleme sistemleri için yüksek verim söz konusudur. Örneğin Pichia pastoris ıslak hücre kütlesinin gramı başına $0.5 \mathrm{mg}$ kadar CCMV ekspresyonu elde edilir. Mayalarda heterolog sentezleme genetik olarak değiştirilmiş nükleik asidin ya da kapsitlerin büyük ölçekli üretimine izin verir. Heterolog sentezlemenin başlıca avantajı, virüs partiküllerinin doğal konukçu hücrelerinde birikmesine izin vermesidir. BMV partikülleri bitkilerde ya da Saccharomyces cerevisiae'nin heterolog sentezleme sistemi içinde üretilebilir [10]. Bundan başka, CCMV ya da BMV virüs benzeri parçacıkların k1lıf protein monomerlerinin laboratuvar şartlarında kendini çoğalttığı bulunmuştur. [7,8]. CCMV ve BMV partikülleri $\mathrm{pH}$ değişimine ve iyon metallerine bağlı olarak yapısal değişim geçirebilir. [5,8] $\mathrm{Bu}$ yapısal geçişler, virüsün boyutunda yaklaşık \%10'luk bir artış ile sonuçlanmaktadır. Yapısal geçiş, virüs partikülünün ekseninin 3 kat artışının sonucudur, protein kılıfındaki ayrı iki nm büyüklüğünde 60 farklı açıklığın oluşumu ile şekillenmektedir [1].

RCNMV Tombusviridae familyasından bir iki parçalı ssRNA virüsüdür. Bu partikül formları ikosahedral simetri ve yaklaşık 36 nm'lik bir çapa sahiptir [11]. CarMV aynı aileden aynı simetrili bir kapsite sahiptir [12]. TYMV Tymoviridae familyasının bir üyesi, 28 nm'lik bir çapa sahip olan bir ssRNA virüsüdür. 180 kimyasal özdeş protein alt birimi 60 trimerik asimetrik birimler halinde düzenlenmiştir [13]. Comoviridae familyası Comovirüs cinsinin üyesidir. Hayvan picornovirüslerinin çoğalmasına, genom organizasyonuna ve yapısına benzerlik gösteren bir bitki virüsüdür [14]. CPMV'nin yapısı atomik çözünürlüğe yakındır. [15]. CPMV virionları ikosahedral simetri gösterirler ve ikosahedral beş kat ve ayrıca üç kat ekseninde çıkıntılar gösterir. Partiküllerin çapı 28 nm'dir. Bu virionlar protein kılıfların küçük (S, small) ve büyük (L, large) alt birim olarak isimlendirilen iki farklı tipi tarafindan oluşturulmuştur. S alt ünitesinin A olarak isimlendirilen bir alanı, L alt ünitesinin B ve C olarak isimlendirilen 2 alanı mevcuttur [1].

TMV ise $300 \mathrm{~nm}$ boyunda, $9 \mathrm{~nm}$ çapında düz, çubuk şeklinde partikülleri vardır. Bir heliks üzerinde paketlenmiş gibi görünen 2140 benzer alt üniteden oluşmuştur [16].

\subsection{Virüs Yüzeyinin Belirginleştirilmesi}

Çok katmanlı ışınlar gibi yeni materyallerin hazırlanabilmesi için, protein kılıf yüzeyinin biyolojik ve kimyasal molekül parçaları ile belirginleştirilmesi gerekmektedir. Bu şekilde, işlevsel hale getirilmiş nanobloklar inşa edilebilir. CCMV, CPMV ve TYMV'nin çok sayıda molekülle düzenlenebilecek, belirginleştirilebilecek amino asiti vardır. Virüslerin aspartik ve glutamik asitten elde edilen lysine ve karboksilat grupları vardır. Standart amin ve karboksi seçici biyokonjugasyon teknikleri kullanılarak çok sayıda farklı grup bağlanabilir. Örneğin CCMV'ye yaklaşık 540 lsysine kalıntısı ve 560 karboksilat eklenebilir. TYMV'ye yaklaşık 60 lysin ve 90-120 karboksilat grubu eklenebilir [17]. Yabani tip virüslere ek olarak genetik mühendislikle elde edilmiş mutantların yüzeylerine de sistein ve histidinler eklenebilir. İkosahedral virüsler dışında TMV de florasan boyalar ve diğer küçük moleküllerin eklenmesi için bir iskele olarak kullanılabilir. Son yıllarda özellikle CPMV'ün yabancı tip ve mutant virionlarına 
biyolojik, organik ve inorganik moleküller eklenerek nanoyapı blokları elde edilmiş ve bun bloklar viral nanopartikül kaynağı olarak kullanılmıştır [1].

\subsection{Viral Nanopartiküller}

Virüsler konukçu hücrelerine özelleşmiş ve genetik materyallerini bu hücrelerde çoğaltarak yayılma özelliğine sahiptir. Dolayısıyla virüsler hedeflenmiş ilacın iletilmesinde veya dokuya özel görüntüleme kimyasallarında kullanım için ideal bir temel teşkil etmektedir. Viral nanopartiküller (viral nano particles, VNP) ve virüs benzeri partiküller (virus like particles, VLP) bitkilerden veya bakterilerden elde edilebilirler. VNP ve VLP hem biyolojik olarak uyumlu olup, hem de biyolojik olarak çözünmemektedirler. İnsanlar ve diğer memelilerde zararlı değildirler. VNP'ler, iyi analiz edilmiş monodispers özellikleri (atomik rezolüsyonda çözünmeleri) ve büyük miktarlarda üretilebilmeleri sebebi ile tercih edilmektedirler. Nanoteknolojik araştırmalarda atomik boyutlara kadar sivriltilmiş bir iğne ucu yardımıyla, yüzeyin yüksek çözünürlükte, üç boyutlu görüntülenmesi sağlanır. Görüntüleme, iğne ucunun yüzey ile etkileşiminin incelenmesi sonucunda gerçekleştirilir. Yüksek oranda simetrik yapı göstermeleri nedeniyle doğadaki en gelişmiş ve çok yönlü nano materyaller arasında yer almaktadır. VNP'lerin dış yüzeylerinin hücreye özel taşınmayı sağlayan hedef ligandlarla düzenlenebilmesi özeliğinden dolayı, ilaç molekülleri, görüntüleme kimyasalları, kuantum noktaları ve diğer nanopartiküllerle kaplanabilmektedirler [18].

\subsection{Viral Nanopartiküllerin Üretimi}

VNP'ler doğal konukçularında yüksek titrelerde üretilebilirken; VLP'ler heterolog sentezleme sistemlerinde daha kolay üretilebilirler. VNP'ler arasında brom otu mozaik virüsü (Brome mosaic virus, BMV), börülce klorotik benek virüsü (Cowpea chlorotic mottle virus, CCMV), börülce mozaik virüsü (Cowpea mosaic virus, CPMV) Patates X virüsü (Potato virus X, PVX) ve tütün mozaik virüsü (Tobacco mosaic virus, TMV) konukçularında yüksek oranda üretilebilir. VNP'ler ise QB, MS2, HK97 VE M13 kültürlerinde Escherichia coli bakterisi kullanılarak üretilebilir. VNP'ler kimerik (mutant CVNP'ler) Escherichia coli ve maya gibi heterelog ekspresyon sistemleriyle üretilirler. VLP'ler ayrica VNP lerden $\mathrm{pH}$ ile teşvik edilip büyütülerek ve daha sonra salınan nükleik asitlerin alkalin hidrolizi ile direkt elde edilir. Alternatif olarak VNP ler bireysel kılıf protein alt ünitelerinde çoğaltılıp nükleik asiti çıkarılan VLP'lerde tekrar çoğaltılabilir [1].

\section{Bitki Patojeni Virüslerin Nanoteknolojideki Kullanım Alanları}

\subsection{Filmler, Tabakalar, Işınlar}

Sıralanmış, nanoyapılı filmler, tabakalar ve ışınlar; sensörlerde, optoelektronikte, nanoelektronikte ve biyomedikal uygulamalarda kullanım alanı bulmuştur [1]. Kristalizasyon teknikleri üç boyutlu organizasyonlarda orta ölçekte kullanılabilir. Örneğin ikosahedral partikülleri olan, CPMV $1 \times 10^{13}$ sıralanmış partikülü $1 \mathrm{~mm}^{3}$ kristale dönüşebilir [19]. CPMV ayrıca birbirine karışmayan iki sıvı arasındaki ortak yüzeyde de çoğalabilir. Virüs partikülleri, perflorodekalin-su arayüzeyinde ayrılabilir ve yağ damlacıklarının dispersiyonunda sabitlenebilir. Yağ-su ortak yüzeyinde partiküllerin çapraz 
bağlanmasıyla glutaraldehit ya da biyotin/avidin bağlanarak gösterilebilir. Böylece güçlü bir membran oluşturulabilir ve virüs partiküllerinin bütünlüğü bozulmaz [20].

Çubuk şekilli TMV alternatif bir teknikle; virüs süspansiyonu katı bir yüzey üzerinde nematik sıvı kristalde çözdürülerek silika ile çoğaltılabilir ve TMV likid sıvı kristalleri termal degradasyonu takiben slikondioksit elde edilebilir [21].

Yüzeydeki viral nanopartiküller tek katmanlar üretmek için kullanılabilir. TMV hem altına kovalent olmayan bağlarla, hem de mika, cam ve slikon gibi hidroksil içeren yüzeylere adsorbe edilebilir. $\mathrm{Bu}$ amaçla genetik olarak değiştirilmiş CPMV ve CCMV virionları kullanılabilir. Bu yaklaşım nanometre boyutlu yapı geliştirme teknikleriyle kombine edilerek viral partiküllerin montajı sağlanabilir. Benzer bir metotla CPMV'nin mutant partikülleri altın yüzey üzerinde depolanarak üniform bir tek katman elde edilebilir ve bu viral partiküller için uygun boya kullanılarak floresan mikroskopta görüntülenebilir [2224].

Alternatif olarak viral nanopartiküller biyotin avidin ile yapılan modifikasyonlarda kullanılabilir. Biyotinle etiketlenmiş CPMV streptavidin ile uygulanmış yüzeylere kolaylıkla bağlanabilir. Biyotin streptavidin interaksiyonu ayrıca viral nanopartiküllerden üç boyutlu ışınlar elde etmede kullanılabilir [25].

\section{2. Çubuklar, Teller ve Borular}

İlk çalışmalarda çubuk şeklinde olan TMV, nanotübüler inorganik materyallerin mineralizasyonu için şablon olarak kullanılmıştır. TMV'nin dış yüzeyi PbS ya da CdS ile kaplanmış ve silika ve demir oksitle yoğunlaştırılmıştır [26]. Bu çalışmadan sonra TMV kobalt, nikel, demir, paladyum, platin, gümüş, silika, titanyum ve alüminyum oksit gibi pekçok maddenin kaplanmasında kullanılmıştır [27-36].

Metal nanoteller, TMV nin dış yüzeyine metalik salkımlar eklenerek veya 4 nm'lik orta kanalı şablon olarak kullanılarak hazırlanabilir. Örneğin dış yüzeyi paladyum, platin veya altın salkımlarıyla kaplanabilir veya nikel ve kobalt salkımlarının içine işleyebileceği bir kılıf kullanılabilir [32].

TMV şablon olarak kullanılarak $\mathrm{CoPt}, \mathrm{CoPt}_{3}$ ve $\mathrm{FePt}_{3}$ bimetalik ve ferro manyetik nanoteller, metal tuzlar ve ultra ses dalgalarıla üretilebilirler. Ultra sonikasyon, nanotelin kanal içerisinde büyümesini ve onların üniform çap oluşturmasını sağlar [37]. TMV ayrıca şablon olarak nonmetalik monodispers polimerik iletken nanotellerin oluşumunda ve nano iplik yapımında da kullanılmıştır [38].

CPMV üç boyutlu iletken moleküler ağda nano iskelet olarak, 60-120 cyteine tiyolleri içeren CPMV mutantları ise altın nano partikül üretiminde kullanılmıştır. Altın nanopartikülleri moleküler tellerle birleştirildiğinde kılıf protein yüzeyine iletkenlik özelliği kazandırmıştır. Bu sistem ile nano elektrik devrelerinin oluşturulması önemli yararlar sağlanmaktadır [39].

\subsection{Tiptaki Uygulamalar}

Tiptaki uygulamalar için hem sentetik materyaller, hem de VNP gibi doğal biyomateryaller ve genom içermeyen kopyaları VLP'ler gibi çeşitli nanopartiküller geliştirilmiştir. VNP/VLP formülasyonlarının ilaç ve kimyasalların yüklerini görüntülemek için genetik ve kimya mühendisliği metotları kullanılmıştır. Ayrıca hedeflenmiş VNP ve VLP'ler partikül yüzeyine peptit ligandları eklenerek çoğaltılabilir [18]. 
Bulaşıcı hastalıklar için geliştirilen çeşitli aşılar memelilerin VLP'leri esasına dayanmakta ve hali hazırda kliniklerde kullanılmaktadır [40]. Ayrıca kanserin önlenmesi içinde geliştirilmişlerdir [41,42]. İnsan hastalıklarını taşıyan viral gen en son teknoloji kullanılarak memeli virüs vektörlerinden elde edilmiştir [43]. Bazı adjuvantlar insan aşıları için kullanılmaktadır. Örneğin hepatit, HIV, sıtma, kanser gibi viral ve parazit enfeksiyonlar için yeni aşılar geliştirilmiştir. Bağışıklığı güçlendiren ve dağıtan bu yardımcı maddeler hümoral, hücresel ve mukozal bağışıklı̆ğ ortaya çıkarma yeteneğindedir [40].

Vücuda alınan ilaçlar, normalde vücudun her yerine dağılmakta ve gerçek hedefe gitme olasılığı azalmaktadır. Halbuki nano partiküller ile ilacın doğrudan doğruya hedefe gönderilebilmesi mümkündür. Bunu, hedefi vuran nano kurşuna benzetebiliriz. Böylece ilaç doğrudan doğruya hasta bölgeye veya hasta dokuya gönderilebilmektedir. Mevcut yöntemlerle ilaç alımında, vücudun küçük bir bölgesini tedavi etmek için vücudun başka bir yerini zehirlemek gibi bir risk bulunmaktadır ve bu verimsiz bir yöntemdir. Klasik yöntemle ilaç kullanımında, vücudun kritik iç organları, beyin, karaciğer, böbrek vb. zarar görebilmektedir. Halbuki nano teknoloji ile yapılan tedavide, ilaç nano kapsüllere yüklenmekte ve bu nano kapsüller şırınga ile sadece hasta bölgeye verilmektedir. Daha sonra da nano kapsüller patlatılmakta ve sadece gerekli yerlere ilaç zerkedildikten sonra da bu zararsız nano kapsüller vücuttan dişarı atılmaktadır [44].

Yapılan bir çalışmada insanlara ilk gen terapisi denemelerinde bir Retrovirus kullanarak insanlarda tümörü infiltre eden lenfositlerin içine neomisin ile dayanıklılığı kodlayan gen katılmıştır [43].

İlaçlar doksorubisin, paklitaksel, higromisin ve diğer sitotoksinler gibi hedeflenmiş RCNMV, HCSRV (Hibiscus chlorotic ringspot virus), MS2 ve M13 E. coli bakteriyofaj formülasyonları üzerine yüklenmiş ve her bir durumda spesifik kanser hücresini öldüren kültürlenmiş hücrelerden elde edilmiştir [45-48]. Alternatif bir yaklaşım olarak fotodinamik tedavide (PDT), nanoteknolojide çok kullanılan bir karbon allotropu ailesi üyesi olan 60 karbonlu C60 fulleren, VNP konjugatları ile CPMV ve Q $\beta$ bakteriyofajına entegre edilmiş ve fotokimyasal değişim sürecinde kullanılmıştır [49]. Stafilokokus hedefli rutenyum CCMV konjügatları, bakteriyel enfeksiyonlar [50] ve porfirin yüklü MS2 partikülleri lösemi tedavisine özgü reseptör aptamerler kullanarak hedefli T-hücreleri geliştirilmiştir [51]. Virüslerin nükleik asitleri gen terapisi için vektörlere aktarılmaya son derece uygundur ve bir kaç memeli virüsü bu şekilde klinik muayene çalışmalarında incelenmiştir [43].

\subsection{Bitki Patojenlerinin Kontrolünde Nanoteknoloji}

Nanoteknoloji alanı, tarım için yeni potansiyel uygulamalar açmıştır. Nanoteknolojik uygulamalar hali hazırda tıp ve eczacılıkta kullanılmakta olup, bitki koruma alanında da yerini almaya başlamıştır. Nanokapsüller parazit yabancı otlara karşı sistemik herbisit kullanımında ürün üzerinde fitotoksisiteyi önlemeye yardımcı olmaktadır. Nanoenkapülasyon aktif maddelerin yavaş ve sabit alımına izin veren kutikula ve doku ile dahi nüfuz sağlayıp öldürücü dozun azaltılmasına yardımcı olmuştur. Parazit bitkilerin kontrolü için nanoenkapsülasyon parazit yabancı otlara karşı kullanılan herbisitlerin ürün üzerinde fitotoksisite ile ilgili problemlerini çözmek için kullanılabilecektir. Örneğin, canavar otu (Orobanche spp.) tüberkülleri hem besinler ve su için hem de sistemik herbisitler için güçlü rol oynadığ bilinmektedir. Nanoenkapsüllü herbisitler uygulanırsa üründe fitotoksisite sorunları veya detoksifikasyon 
sistemik sorunları önlenmektedir. Nanokapsüllü herbisitler parazit yabancıota ulaşınca en kısa zamanda herbisiti serbest birakarak etkisini gösterir [52].

Herbisitin salımı, parazitik yabancı ot ya da uygulama sonrası sadece bir süre içinde belirli koşullar altında aktive edilebilir. Diğer herbisitlerin enkapsülasyonu ayrıca uygulamada iyileştirmeler sağlayabilir. Sülfonilüre herbisitler, canavarotuna karşı (Orobanche spp.) topraktan uygulanmaktadır ancak daha etkin bir kontrol sağlamak için farklı uygulamalar yapılması gerekmektedir. Canavarotuna karşı başka bir uygulamada ise paramanyetik nanopartiküller kullanılmıştır. Bu tür nanopartiküller Orobanche veya Striga tüberküllerinin içinde sıcaklığın etkisiyle birikmiştir. Böylece nanopartiküllerin kökler ve tohumlar tarafından daha fazla emilimi sağlanarak manyetik nanopartiküllerle kaplanmıştır. Böylelikle ekim ve sonrasında, toprağı işleme sırasında parazit yabancı otlar elemine edilebilmiştir [52]. Yapılan bir çalışmada domatese bitki virüsü nanopartiküllü Abamektin (nematisit özelliği olan pestisit) uygulanmış ve domateslerde kök-ur nematoduna (Meloidogyne hapla) karşı fide köklerinin sağlıklı geliştiği ve köklerde ur oluşumunda azalma olduğu görülmüştür [53]. Nematotlarla ilgili bir diğer çalışmada ise nematisitlerin toksik etkilerinden dolayı, kontrollü salınımları için yeni bir sistem geliştirlmeye çalışılmış ve bitki virüsü temelli, küçük molekül salınımlı bir ilaçlama sistemi geliştirilmiştir. Bu dağıtım sistemi tohum kaplama formülasyonları ile birlikte bitki viral nano partikülleri ihtiva eden nematisitleri içermektedir. Nematisitlerin bitki viral nanopartikülleriyle enkapsülasyonu sonucu; hedef olmayan alanlardaki olumsuz etkileri elemine edilmiş ve bu uygulamanın tohum kaplama biçimi olan granül nematisit uygulamarından daha ekonomik ve çevreci olduğu bildirilmiş̧ir [44].

\section{Sonuç}

Sonuç olarak nanoteknoloji araştırmaya çok açık ve gelişmekte olan bir bilim dalıdır. Bitki virüs partikülleri materyal ve araçların yapımında nano seviyede kullanılabilir. Kataliz elektronik sensör ve ilaç sektöründe ileride çok işe yarayabileceği düşünülmektedir. Ayrıca gelecekte nanobiyolojik ürünler gündeme gelecek, suni organ yapımında nano parçalar kullanılıp anında teşhis koyabilen sağlık tarama araçları yapılabilecektir.

\section{Kaynaklar}

[1] Evans D.J., "The bionanoscience of plant viruses: templates and synthons for new materials" United Kingdom. Journal of Materials, 18, 3746-3754, 2008

[2] Wellink J., "From Virus Isolation to Transgenic Resistance" Methods in Molecular Biology, 81, 205-209, 1998

[3] Brumfield S., Willits D., Tang L., Johnson J.E., Douglas T., Young M., "Heterologous expression of the modified coat protein of Cowpea chlorotic mottle bromovirus results in the assembly of protein cages with altered architectures and function" Journal of General Virology, $85,1049-1053,2004$

[4] Lucas R.W., Larson S.B., McPherson A., "The crystallographic structure of brome mosaic virüs" Journal of Molecular Biology, 317, 95-108, 2002 
[5] Speir J.A., Munshi S., Wang G., Baker T.S., Johnson J.E., "Structures of the native and swollen forms of cowpea chlorotic mottle virus determined by X-ray crystallography and cryo-electron microscopy" Structure, 3, 63-78, 1995

[6] Smith T.J., Chase E., Schmidt T., Perry K.L. "The structure of cucumber mosaic virus and comparison to cowpea chlorotic mottle virüs” Journal of Virology,74,16, 7578-7586, 2000

[7] Zhao X., Fox J.M., Olson N.H., Baker T.S., Young M.J., "Virion swelling is not required for cotranslational disassembly of cowpea chlorotic mottle virus in vitro" Virology, 207, 486-494, 1995

[8] Cuillel M., Berthet-Colominas C., Krop B., Tardieu A., Vachette P., Jacrot, B., "Self-assembly of brome mosaic virus capsids: kinetic studies using neutron and X-ray solution scattering" Journal of Molecular Biology, 164, 645-650, 1983

[9] Schneemann A., Young, M.J., "Viral assembly using heterologous expression systems and cell extracts" Advances in Protein Chemystry, 64, 1-36, 2003

[10] Liepold L.O., Revis J., Allen M., Oltrogge L., Young M., Douglas, T., "Structural transitions in Cowpea chlorotic mottle virus (CCMV)" Physical Biology, 2, 166-172, 2005

[11] Sit T.L., Vaewhongs A.A., Lommel S.A., "RNA-mediated trans-activation of transcription from a viral RNA” Science, 281, 829-832, 1998

[12] Lvov Y., Haas H., Decher G., Möhwald H., Mikhailov A., Mtchedlishvily B., Morgunova E., Vainshtein B., "Successive deposition of alternate layers of polyelectrolyds and a charged virüs" Langmuir., 10, 4232-4236, 1994

[13] Canady M.A., Larson S.B., Day J., McPherson, A., "Crystal structure of turnip yellow mosaic virüs" Nature Structial Biology, 3, 771-781, 1996

[14] Lin T., Johnson J.E., "Structures of picorna-like plant viruses: implications and applications" Advances in Virus Research, 62, 167-239, 2003

[15] Lin T., Chen Z., Usha R., Stauffacher C.V., Dai J.B., Schmidt T., Johnson, J.E., "The refined crystal structure of cowpea mosaic virus at 2.8 A resolution"Virology, 265, 20-34, 1999

[16] Caspar D.L.D., “Assembly and Stability of the Tobacco Mosiac Virus Particle" Advances in Protein Chemistry, 18, 37-121, 1963

[17] Gillitzer E., Willits D., Young M., Douglas T., "Chemical modification of a viral cage for multivalent presentation” Chemical Communications, 2390-2391, 2002

[18] Y1ldı İ., Shukla S., Steinmetz N.F., "Applications of viral nanoparticles in medicine" Current Opin Biotechnology, 22, 901-908, 2011

[19] Wang Q., Lin T., Tang L., Johnson J.E., Finn, M.G., "Icosahedral virus particles as addressable nanoscale building blocks" Angewandte Chemie., Int. Ed. 41, 459-462, 2002

[20] Russell, J.T., Lin Y., Böker A., Su L., Carl P., Zettl H., He J., Sill K., Tangirala R., Emrick T., Littrell K., Thiyagarajan P., Cookson D., Fery A., Wang Q.,Russell, T.P., "Self-assembly and cross-linking of bionanoparticles at liquid-liquid interfaces" Angewandte Chemie., Int. Ed. 44, 2420-2426, 2005 
[21] Kuncicky D.M., Naik R.R., Velev, O.D., "Rapid Deposition and Long-Range Alignment of Nanocoatings and Arrays of Electrically Conductive Wires from Tobacco Mosaic Virus" Small., 2, 1462-1466, 2006

[22] Klem M.T., Willits D., Young M., Douglas, T., "2-D Array Formation of Genetically Engineered Viral Cages on Au Surfaces and Imaging by Atomic Force Microscopy" Journal of the American Chemical Society, 125, 10806-10807, 2003

[23] Smith J.C., Lee K.B., Wang Q., Finn M.G., Johnson J.E., Mrksich M., Mirkin, C.A., "Nanopatterning the Chemospecific Immobilization of Cowpea Mosaic Virus Capsid" Nano Letters, 3, 883-886, 2003

[24] Cheung C.L., Camarero J.A., Woods B.W., Li T., Johnson J.E., De Yoreo J.J., "Fabrication of assembled virus nanostructures on templates of chemoselective linkers formed by scanning probe nanolithography” Journal of the American Chemical Society, 125, 6848-6849, 2003

[25] Steinmetz N.F., Lomonossoff G.P., Evans D.J., "Cowpea mosaic virus for material fabrication: addressable carboxylate groups on a programmable nanoscaffold” Langmuir., 22, 10032-10037, 2006

[26] Shenton W., Douglas, T., Young, M., Stubbs, G., Mann, S., "Inorganic-Organic Nanotube Composites from Template Mineralization of Tobacco Mosaic Virus" Advanced Materials, 11, 253-256, 1999

[27] Balci S., Bittner A.M., Hahn K., Scheu C., Knez M., Kadri A., Wege C., Jeske H., Kern K., "Copper nanowires within the central channel of tobacco mosaic virus paricles" Electrochimica Acta, 51, 6251-6357, 2006

[28] Dujardin E., Peet C., Stubbs G.,. Culver J.N., Mann S., “Organization of Metallic Nanoparticles Using Tobacco Mosaic Virus Templates” Nano Letters, 3, 413-417, 2003

[29] Knez M., Bittner A. M., Boes F., Wege C., Jeske H., Maiß E., Kern K., "Biotemplate Synthesis of 3-nm Nickel and Cobalt Nanowires” Nano Letters, 3, 1079-1082, 2003

[30] Knez, M., Kadri A., Wege C., Gosele U., Jeske H., Nielsch K., “Atomic Layer Deposition on Biological Macromolecules: Metal Oxide Coating of Tobacco Mosaic Virus and Ferritin” Nano Letters, 6, 1172-1177, 2006

[31] Knez, M., Sumser M., Bittner A.M., Wege C., Jeske H., Kooi S., Burghard M., Kern K., "Electrochemical modification of individual nano-objects" Journal of Electroanalitical Chemistry, 522, 70-74, 2002

[32] Knez M., Sumser M., Bittner A.M., Wege C., Jeske H., Martin T.P., Kern K., "Spatially selective nucleation of metal clusters on the tobacco mosaic virus" Advanced Functional Materials, 14, 116-124, 2004

[33] Lee, S.Y., Choi J., Royston E., Janes D.B., Culver J.N., Harris M.T., "Deposition of platinum clusters on surface-modified tobacco mosaic virus" Journal of Nanoscience and Nanotechnology, 6, 974-981, 2006

[34] Lee S.Y., Royston E., Culver J.N., Harris M.T., "Improved metal cluster deposition on a genetically engineered tobacco mosaic template" Nanotechnology, 16, 435-441, 2005 
[35] Royston E., Lee S.Y., Culver J.N., Harris M.T., "Characterization of silica-coated tobacco mosaic virüs” Journal of Colloid and Interface Science, 298, 706-712, 2006

[36] Fujikawa S., Kunitake T., "Surface Fabrication of Hollow Nanoarchitectures of Ultrathin Titania Layers from Assembled Latex Particles and Tobacco Mosaic Viruses as Templates" Langmuir, $19,6545-6552,2003$

[37] Tsukamoto R., Muraoka M., Seki M., Tabata H., Yamashita I., "Synthesis of CoPt and FePt3 nanovires using the central channel of tobacco mosaic virus as a biotemplate" Chemistry of Materials, 19, 2389-2391, 2007

[38] Tseng R.J., Tsai C., Ma L., Ouyang J., Ozkan C.S., Yang Y., "Digital memory device based on tobacco mosaic virus conjugated with nanoparticles" Nature Nanotechnology, 1, 72-75, 2006

[39] Blum A.S., Soto C.M., Wilson C.D., Brower T.L., Pollack S.K., Schull T.L., Chatterji A., Lin T.W., Johnson J.E., Amsinck C., Franzon P., Shashidhar R., Ratna B.R., "An engineered virus as a scaffold for three-dimensional self-assembly on the nanoscale” Small, 1, 702-706, 2005

[40] Peek L.J., Middaugh C.R., Berkland C., "Nanotecnology in vaccine delivery" Advanced Drug Delivery Review, 60, 915-928, 2008

[41] McAleer W.J., Markus H.Z., Wampler D.E., Buynak E.B., Miller W.J., Weibel R.E., McLean A.A., Hilleman M.R., "Vaccine against human hepatitis B virus prepared from antigen derived from human hepatoma cells in culture" Proceedings of Society for Experimental Biol Med., $175,3,314-319,1984$

[42] Villa L.L., Ault K.A., Giuliano A.R., Costa R.L., Petta C.A., Andrade R.P., Brown D.R., Ferenczy A., Harper D.M., Koutsky L.A., Kurman R.J., Lehtinen M., Malm C., Olsson S.E., Ronnett B.M., Skjeldestad F.E., Steinwall M., Stoler M.H., Wheeler C.M., Taddeo F.J., Yu J., Lupinacci L., Railkar R., Marchese R., Esser M.T., Bryan J., Jansen K.U., Sings H.L., Tamms G.M., Saah A.J., Barr E., "Prophylactic quadrivalent human papillomavirus (types 6, 11, 16, and 18) L1 virus-like particle vaccine in young women: a randomised double-blind placebocontrolled multicentre phase II efficacy trial” The Lancet Oncology, 6, 5, 271-278, 2005

[43] Edelstein M.L., Abedi M.R., Vixon R.M., Edelstein, M., "Gene therapy clinical trials worldwide 1989-2004-an overview” The Journal of Gene Medicin, 6, 6, 597-602, 2004

[44] Anonymous, "http://licensing.research.ncsu.edu/technologies/12018_plant-virus-and-nonwoven-fiber-nanotechnology-delivery-system-for-agricultural-applications" (online access 29 nisan 2016). 2016

[45] Ren Y., Chan L.W.U., "Application of HCRSV protein cage for anticancer drug delivery. PhD thesis, Departtment of Pharmacy" National University of Singapore, 2007

[46] Loo L., Guenther R.H., Lommel S.A., Franzen S., "Encapsidation of nanoparticles by red clover necrotic mosaic virüs" Journal of the American Chemical Society, 129, 36, 11111-11117, 2007

[47] Acosta-Ramirez E., Perez-Flores R., Majeau N., Pastelin-Palacios R., Gil-Cruz C., Ramirez Saldana, M., Manjarrez Orduno N., Cervantes Barragan L., Santos Argumedo L., Flores Romo L., Becker I., Isibasi A., Leclerc D., Lo'pez-Mac1'as C., “ Translating innate response into longlasting antibody response by the intrinsic antigen-adjuvant properties of papaya mosaic virüs" Immunology, 124, 2, 186-197, 2008 
[48] Brown W.L.,Mastico R.A., Wu M., Heal K.G., Adams C.J., Murray J.B., Simpson J.C., Lord J.M., Taylor-Robinson A.W., Stockley P.G., "RNA bacteriophage capsid-mediated drug delivery and epitope presentation” Intervirology, 45, 371-380, 2002

[49] Steinmetz N.F., Manchester M., "PEGylated viral nanoparticles for biomedicine. the impact of PEG chain length on VNP cell interactions in vitro and ex vivo" Biomacromolecules., 10, 4, 784-792, 2009

[50] Suci P.A., Varpness Z., Gillitzer E., Douglas T., Young M., “Targeting and photodynamic killing of a microbial pathogen using protein cage architectures functionalized with a photosensitizer” Langmuir., 23, 24, 12280-12286, 2007

[51] Stephanopoulos N., Tong G.J., Hsiao S.C., Francis M.B., "Dual-Surface Modified Virus Capsids for Targeted Delivery of Photodynamic Agents to Cancer Cells" Acs Nano., 4, 10, 6014-6020, 2010

[52] Luque A.P., Rubiales, D., "Nanotechnology for parasitic plant control” Pest Management Sci.; $65,5,540-545,2009$

[53] Cao J., Guenther R.H., Sit T.L., Lommel S.A., Opperman C.H., Willoughby J.A., “Development of abamectin loaded plant virus nanoparticles for efficacious plant parasitic nematode control" ACS Applied Materials and Interfaces., 13,7, 18, 9546-9553, 2015 